\title{
Validation of nine years of MOPITT V5 NIR using MOZAIC/IAGOS measurements: biases and long-term stability
}

\author{
A. T. J. de Laat ${ }^{1}$, I. Aben ${ }^{2}$, M. Deeter ${ }^{3}$, P. Nédélec ${ }^{4}$, H. Eskes ${ }^{1}$, J.-L. Attié ${ }^{4,5}$, P. Ricaud ${ }^{5}$, R. Abida ${ }^{5}$, L. El Amraoui ${ }^{5}$, \\ and J. Landgraf ${ }^{2}$ \\ ${ }^{1}$ Royal Netherlands Meteorological Institute, de Bilt, the Netherlands \\ ${ }^{2}$ Netherlands Space Research Institute, Utrecht, the Netherlands \\ ${ }^{3}$ National Center for Atmospheric Research, Boulder, USA \\ ${ }^{4}$ Laboratoire d'Aérologie-OMP, Université de Toulouse - CNRS/INSU, UMR5560, Toulouse, France \\ ${ }^{5}$ CNRM-GAME Météo-France/CNRS UMR 3589, Toulouse, France \\ Correspondence to: A. T. J. de Laat (laatdej@knmi.nl)
}

Received: 3 April 2014 - Published in Atmos. Meas. Tech. Discuss.: 2 June 2014

Revised: 19 August 2014 - Accepted: 1 October 2014 - Published: 18 November 2014

\begin{abstract}
Validation results from a comparison between Measurement Of Pollution In The Troposphere (MOPITT) V5 Near InfraRed (NIR) carbon monoxide (CO) total column measurements and Measurement of Ozone and Water Vapour on Airbus in-service Aircraft (MOZAIC)/In-Service Aircraft for a Global Observing System (IAGOS) aircraft measurements are presented. A good agreement is found between MOPITT and MOZAIC/IAGOS measurements, consistent with results from earlier studies using different validation data and despite large variability in MOPITT CO total columns along the spatial footprint of the MOZAIC/IAGOS measurements. Validation results improve when taking the large spatial footprint of the MOZAIC/IAGOS data into account. No statistically significant drift was detected in the validation results over the period 2002-2010 at global, continental and local (airport) scales. Furthermore, for those situations where MOZAIC/IAGOS measurements differed from the MOPITT a priori, the MOPITT measurements clearly outperformed the MOPITT a priori data, indicating that MOPITT NIR retrievals add value to the MOPITT a priori. Results from a high spatial resolution simulation of the chemistry-transport model MOCAGE (MOdèle de Chimie Atmosphérique à Grande Echelle) showed that the most likely explanation for the large MOPITT variability along the MOZAIC-IAGOS profile flight path is related to spatiotemporal CO variability, which should be kept in mind when using MOZAIC/IAGOS profile measurements for validating satellite nadir observations.
\end{abstract}

\section{Introduction}

Carbon monoxide (CO) is an important atmospheric trace gas due to its relevance for the oxidizing capacity of the troposphere (Crutzen and Zimmermann, 1991) as its reaction with the hydroxyl $(\mathrm{OH})$ radical - the atmospheric detergent - is the most important sink of $\mathrm{OH}$. Furthermore, $\mathrm{CO}$ also plays a role in regional air quality and air pollution as a precursor of tropospheric ozone - an important component of air pollution - and is therefore often used to monitor long-range transport of air pollution (e.g. Guerova et al., 2006; Konovalov et al., 2010; Nam et al., 2010; Ghude et al., 2011).

A currently important scientific question is whether the oxidizing capacity of Earth's atmosphere has been changing over the last decades (i.e. Dalsøren and Isaksen, 2006; Montzka et al., 2011). On the one hand, increased air pollution can increase the $\mathrm{OH}$ concentration as its formation is related to tropospheric ozone production. On the other hand, increases in $\mathrm{CO}$ concentrations, and to a lesser extent, in methane $\left(\mathrm{CH}_{4}\right)$ concentrations may reduce atmospheric $\mathrm{OH}$ concentrations as their reactions with $\mathrm{OH}$ form the major sink of atmospheric $\mathrm{OH}$. Furthermore, changes in $\mathrm{OH}$ will affect the atmospheric residence time of $\mathrm{CH}_{4}$ and ozone $\left(\mathrm{O}_{3}\right)$ and thus modify Earth's radiative balance by their warming effect. Because of the dominant role $\mathrm{CO}$ plays in the atmospheric $\mathrm{OH}$ budget, monitoring $\mathrm{CO}$ thus helps in understanding past and present changes in air pollution as well as in certain greenhouse gases. For these reasons, carbon monoxide 
has been identified as an Essential Climate Variable precursor by the World Meteorological Organization (WMO/GCOS).

Because of its typical atmospheric residence time of weeks to months, a reliable estimate of the global $\mathrm{CO}$ budget can only be provided by the use of satellite measurements. For studying long-term changes in $\mathrm{CO}$, it is vital that satellite measurements do not contain biases either in space or time. It is thus important that the satellite measurements are well calibrated and validated.

One of the longest records of measurements of tropospheric constituents from space is actually that of $\mathrm{CO}$ by the US/Canadian Measurement Of Pollution In The Troposphere (MOPITT) mission, which has been operational since March 2000. The MOPITT instrument has been providing the vertical distribution of $\mathrm{CO}$ from measuring thermal InfraRed (IR) radiation emitted by Earth and its atmosphere. MOPITT data have been widely used in many applications (e.g. Worden et al., 2013, and references therein; see also http://www2.acd.ucar.edu/mopitt/refereed-publications).

Apart from measuring IR radiation around $4.7 \mu \mathrm{m}$, the MOPITT instrument also measures in the $2.3 \mu \mathrm{m}$ wavelength range (also known as Near InfraRed or NIR). It was already known - based on measurements by the SCIAMACHY instrument - that useful information on $\mathrm{CO}$ could be derived from NIR wavelengths (e.g. Buchwitz et al., 2004, 2006, 2007; Dils et al., 2006; Sussmann and Buchwitz, 2005; Warneke et al., 2005; Gloudemans et al., 2006). However, due to instrumental issues affecting the data, a useful MOPITT NIR CO product had been still lacking for some time. Only in 2009 was the NIR CO data product delivered by the MOPITT team (Deeter et al., 2009).

In recent years, MOPITT $\mathrm{CO}$ measurements have also been incorporated into data assimilation systems (El Amraoui et al., 2010; Elguindi et al., 2010; Huijnen et al., 2012; Inness et al., 2013; Stein et al., 2014). The assimilation of CO assists in improving long-range transport of air pollution, for example from biomass burning, for improving understanding of stratosphere-troposphere exchange and its representations in numerical weather forecast models as well as for providing the best analysis of the 3-D global distribution of trace gas concentrations and assessing the quality of historical emission databases.

Since the release of MOPITT NIR CO, a first validation study using NOAA (National Oceanic and Atmospheric Administration) aircraft data has shown that the NIR measurements are in good agreement with observations (Deeter et al., 2013), with an average bias of approximately 5-10\% and a 10 -year drift of approximately $0.15 \%$ year $^{-1}$, both thus being insignificant. However, the NOAA measurements have a limited spatial coverage, only providing data over North America, and more validation of MOPITT NIR would be beneficial (opposite to the MOPITT TIR data, which has been much more extensively validated; Deeter et al., 2013, and references therein). An alternative validation data set is available via regular In-Service Aircraft for a Global Ob- serving System (IAGOS) measurements on board of several commercial aircraft. IAGOS is a continuation of the Measurement of Ozone and Water Vapour on Airbus in-service Aircraft (MOZAIC) project that has been providing measurements made on board commercial aircraft since the late 1990s. This data set has already been used for the validation of SCIAMACHY CO measurements (de Laat et al., 2012). Results of validation of MOPITT NIR measurements are presented in this paper. Important aspects of the validation are (1) how our results compare with the validation results of Deeter et al. (2013), (2) can we find indications of spatial biases and (3) is there any long-term drift in the MOPITT measurements, which is important for long-term monitoring of $\mathrm{CO}$.

Furthermore, although used for validation of SCIAMACHY CO, there still is an important open question with regard to the use of MOZAIC/IAGOS data for satellite validation: how representative are the vertically integrated MOZAIC/IAGOS CO profile measurements of a true vertical CO column? Because the MOZAIC/IAGOS profile measurements used for validation of $\mathrm{CO}$ profiles and total columns are obtained during take-off and landing of aircraft, these profiles cover a certain horizontal distance (typically 200-400 km, the so-called "profile flight path"). Because of the lower data quality of SCIAMACHY CO, considerable spatio-temporal averaging of SCIAMACHY was required to reduce SCIAMACHY CO measurement errors to acceptable levels in the study by de Laat et al. (2012). Hence, the question related to the representativity of the MOZAIC/IAGOS CO profiles did not have to be addressed in that study. However, given that MOPITT NIR measurements are of higher quality than those of SCIAMACHY thus not requiring extensive spatio-temporal averaging - and that the size of the MOPITT pixel is considerably smaller (approximately $25 \mathrm{~km}$ ) than the typical profile flight path distance, the question should be asked whether - and how - a single MOPITT measurement should be compared with the MOZAIC/IAGOS profiles. In Deeter et al. (2013) it is assumed that the in situ profile measurements used for validation are representative for a certain horizontal distance, which is not further discussed. A clear answer to this question is important for the use of MOZAIC/IAGOS measurements for validation of current (e.g. MOPITT) and future (e.g. TROPOMI) satellite instruments, but has never been addressed before in detail. This validation study will address this fundamental question and aims to serve as a baseline for future studies on how to use MOZAIC/IAGOS profile measurements for satellite validation.

This paper is organized as follows. Section 2 describes the measurement and model data used in this study, as well as a detailed explanation of the criteria and methods used to collocate and compare MOPITT and MOZAIC/IAGOS measurements. Section 3 presents the validation statistics at global and continental scales. Note that we focus here on the time period 2002-2010, as from 2011 onwards 
there are currently relatively few MOZAIC/IAGOS CO profiles available. Section 4 discusses results for individual MOZAIC/IAGOS airport locations. Section 5 analyses high spatio-temporal chemistry-transport model simulations from the perspective of the spatial representation of MOZAIC/IAGOS CO profile measurements compared to the MOPITT CO total column measurements. Section 6 ends the paper with a summary and a discussion.

\section{Data}

\subsection{MOPITT V5 NIR}

This paper uses the same MOPITT V5 data as in the validation paper of Deeter et al. (2013) which builds on earlier work for MOPITT V4 as outlined in Deeter et al. (2009, 2010) and Worden et al. (2010). We refer to both papers and references therein for the details of the MOPITT V5 retrievals and data set. We simply make a few remarks here about MOPITT V5 NIR data relevant for this study. MOPITT is a gas-filter correlation radiometer rather than a more commonly used grating spectrometer like in SCIAMACHY. It measured $\mathrm{CO}$ at two wavelengths: the thermal infrared around $4.7 \mu \mathrm{m}$ and the near infrared around $2.3 \mu \mathrm{m}$. The spatial resolution of MOPITT measurements is approximately $25 \mathrm{~km}$ with a swath width of $640 \mathrm{~km}$ and MOPITT is in a polar orbit providing global coverage in 3 days. MOPITT has been measuring $\mathrm{CO}$ from the year 2000 onwards and is still operational at the moment of writing.

First of all, the MOPITT NIR CO retrievals obtain information from the $2.3 \mu \mathrm{m}$ first overtone band which is the same wavelength range used by SCIAMACHY. This wavelength range is dominated by reflected solar radiation rather than thermal IR radiation emitted by Earth and the atmosphere. An advantage of this wavelength range is that the vertical sensitivity of NIR retrievals is much more uniform with height (Gloudemans et al., 2008) than that of IR retrievals, which are particularly sensitive to temperature differences between the Earth's surface and the atmosphere just above. On the other hand, the NIR measurements are - amongst others - also determined by the Earth surface NIR reflectance properties. As a result, due to the very low reflectivity of oceans at NIR wavelengths, the signal-to-noise over cloudfree oceans is too low for meaningful NIR retrievals. Hence, only daytime observations over land are available for MOPITT NIR. Note that the combined use of $\mathrm{CO}$ and $\mathrm{CH}_{4}$ retrievals in SCIAMACHY enables meaningful retrievals over clouded ocean scenes as $\mathrm{CH}_{4}$ is used to provide information on the cloud height. However, since MOPITT does not provide $\mathrm{CH}_{4}$ measurements, the same methodology cannot be applied for MOPITT NIR.

MOPITT " $\log (\mathrm{VMR})$ " CO retrievals are performed on a 10-level retrieval grid from the surface to 100 with $100 \mathrm{hPa}$ intervals. All V5 products are processed using a forward model in the retrieval algorithm which explicitly accounts for long-term instrumental changes. This was unaccounted for in earlier MOPITT retrieval versions. In addition, the V5 retrievals account for both instrumental noise and "geophysical noise", i.e. random errors in the calibrated radiances resulting from the combined effects of field-of-view motion and finescale spatial variability in surface radiative properties during each observation (Deeter et al., 2011), whereas all earlier MOPITT retrieval products only accounted for instrumental noise. Finally, MOPITT V5 uses a priori profiles based on a monthly climatology from the global chemical transport model Model for Ozone and Related chemical Tracers, version 4 (MOZART-4). MOZART-4 simulates 100 chemical species with relatively detailed hydrocarbon chemistry, has a horizontal resolution of approximately $3^{\circ} \times 3^{\circ}$ and 28 vertical levels up to $2 \mathrm{hPa}$ (Emmons et al., 2010).

\subsection{MOZAIC/IAGOS}

MOZAIC was initiated in 1993 by European scientists, aircraft manufacturers and airline companies to better understand the natural variability of the chemical composition of the atmosphere and how it is changing under the influence of human activity, with a particular focus on the effects of aircraft. IAGOS is both a continuation and an extension of the MOZAIC research infrastructure. MOZAIC/IAGOS consists of automatic and regular measurements of reactive gases by several long-distance passenger airliners. A large database of measurements (about 30000 flights since 1994) allows studies of chemical and physical processes in the atmosphere and also validation of global chemistry transport models and satellite retrievals. MOZAIC/IAGOS data provide detailed climatologies of trace gases at $9-12 \mathrm{~km}$ and also provide frequent vertical profiles close to a large number of airports.

Carbon monoxide is measured using a Gas Filter Correlation principle, in which infrared absorption of the $4.67 \mu \mathrm{m}$ fundamental vibration-rotation band of CO is used. Different filters are used to modify the infrared radiation between an infrared source and a detector. By comparing the measurements for different filters information about $\mathrm{CO}$ is obtained - see Nédélec et al. (2003) for a detailed explanation of the measurement principle and instrument. The vertical profile measurements of $\mathrm{CO}$ will be used to calculate $\mathrm{CO}$ total columns. Evaluation of MOZAIC/IAGOS CO measurements indicates a precision of $\pm 5 \%$, which is sufficiently accurate for validation purposes (Nédélec et al., 2003). The vertical resolution of raw measurements is $150 \mathrm{~m}(\approx 2 \%$ of the pressure altitude). The MOZAIC/IAGOS database provides automatically selected profiles, based on the distance to the starting point, the pressure difference between the bottom and top of the profile and the fraction of measurements for which there is a consistent change in pressure. A detailed description of the profile determination algorithm can be found in the MOZAIC/IAGOS database. For more information about 
the MOZAIC/IAGOS program see Marenco et al. (1998) or http://mozaic.aero.obs-mip.fr and http://www.iagos.org/.

\subsection{Post-processing, selection criteria and error estimates}

To compare MOPITT NIR and MOZAIC/IAGOS profile measurements, we use the procedure outlined below, which is based on the methodology presented in de Laat et al. (2012) for the use of MOZAIC/IAGOS profile measurements to validate SCIAMACHY CO total column measurements. We focus on the period 2002-2010, as after 2010 there are currently few MOZAIC/IAGOS CO profiles available.

\subsubsection{Vertical representation}

The first filter is to only select MOPITT and MOZAIC/IAGOS profiles for which there are no missing data between 1000 and $300 \mathrm{hPa}$. The $300 \mathrm{hPa}$ altitude is approximately the maximum altitude of MOZAIC/IAGOS measurements. In order to ensure that the profile measurements are representative for a significant part of the troposphere, we only select profiles that start below $800 \mathrm{hPa}$ and measure at least up to $300 \mathrm{hPa}$. Furthermore, every $100 \mathrm{hPa}$ height interval up to $300 \mathrm{hPa}$ must contain at least one measurement. This is the most relevant for MOZAIC/IAGOS measurements, for which sometimes part of the vertical profile is missing. Approximately $6 \%$ of the MOZAIC/IAGOS profiles do not meet the criterion of having at least one measurement every $100 \mathrm{hPa}$ height interval.

\subsubsection{Missing MOZAIC/IAGOS profile information above $300 \mathrm{hPa}$}

The next step is to convert MOZAIC/IAGOS profiles to columns. MOZAIC/IAGOS does not provide measurements above $300 \mathrm{hPa}$ - the flight ceiling of commercial aircraft and the accumulated profile is thus not yet a true $\mathrm{CO}$ total column (see Zbinden et al. (2013) for a discussion of MOZAIC profile measurements in relation to tropopause heights). Furthermore, extending the MOZAIC/IAGOS CO profiles to the highest MOPITT level is mandatory for applying the MOPITT averaging kernel (see Sect. 2.3.4). The missing partial column above the highest altitude where MOZAIC/IAGOS measures is estimated from the MOPITT a priori profile.

De Laat et al. (2012, their Fig. 1) showed that the contribution of the above-MOZAIC/IAGOS profile subcolumn contributes less than $20-30 \%$ to the total column. Because we use the MOPITT a priori to extend the MOZAIC/IAGOS profile to match the MOPITT vertical grid, it is important to know the error of assuming that the MOPITT a priori is reality. For this, we can compare MOPITT with the MOZAIC/IAGOS profile measurements. For $95 \%$ (99\%) of the pixels the differences be-
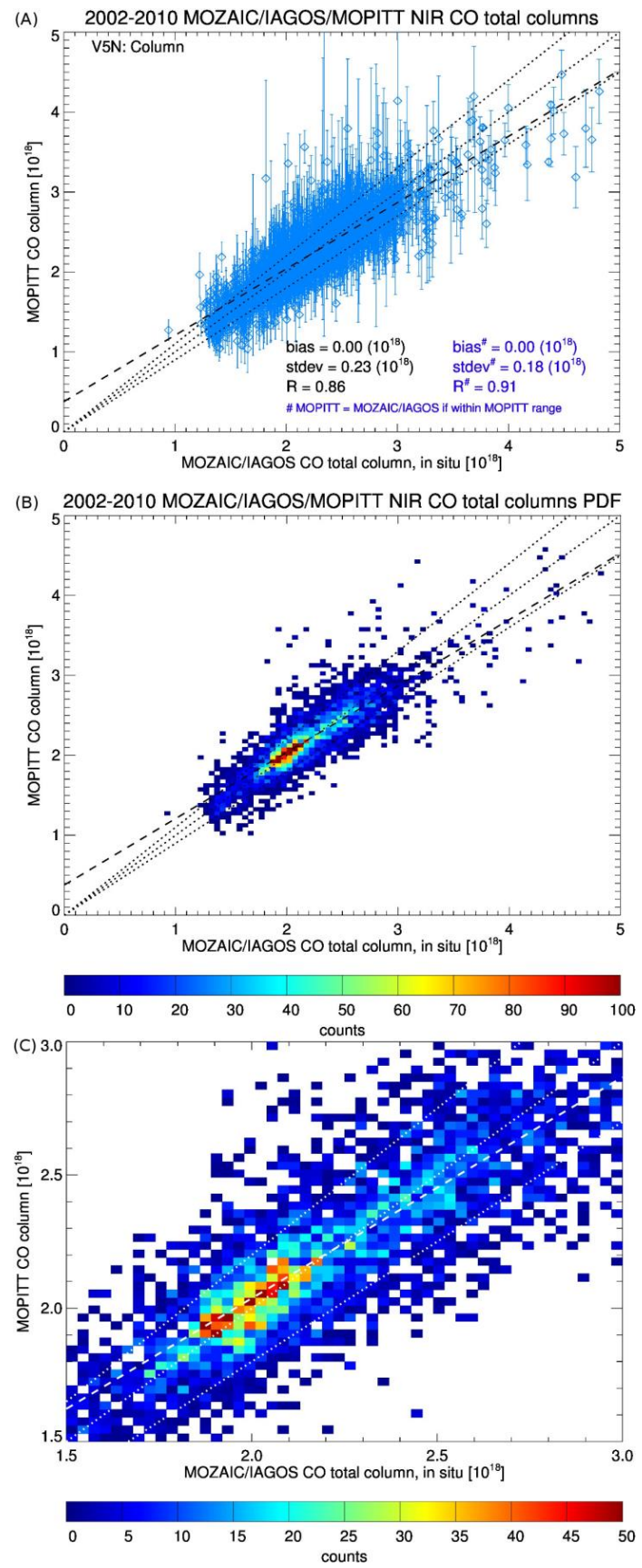

Figure 1. Comparison of all MOPITT and MOZAIC/IAGOS CO total columns for the period 2002-2010. The vertical bars in (a) indicate the range of MOPITT CO total columns that were collocated with the MOZAIC/IAGOS profile path. (b) Shows the scatter distribution of the comparison in (a). (c) Shows a close-up of (b). For the blue statistics in (a) the MOPITT total column is set equal to the MOZAIC/IAGOS total column if the MOZAIC/IAGOS total column value falls within the MOPITT range of $\mathrm{CO}$ total columns. The dotted lines in (b) and (c) indicate the 1:1 line and the $\pm 10 \%$ range; the dashed lines indicate the ordinary linear regression through all data. 
tween MOZAIC/IAGOS and MOPITT a priori total columns are less than $20 \%(30 \%)$, whereas the average MOPITT a priori bias compared to MOZAIC/IAGOS is approximately $10 \%$. Furthermore, $20-30 \%$ of the CO total column is located above $300 \mathrm{hPa}$ - the maximum height reached by MOZAIC/IAGOS. Hence, errors due to adding the MOPITT a priori to the MOZAIC/IAGOS profile for the missing MOZAIC/IAGOS measurements above the maximum MOZAIC/IAGOS altitude are of the order of approximately $5 \%$ and less: $20-30 \%$ of the $\mathrm{CO}$ total column located above $300 \mathrm{hPa}$ multiplied by an average error in the MOPITT a priori of $10 \%$.

Note that rather than adding the a priori estimate of the missing column to the MOZAIC/IAGOS partial column it is also possible to scale the MOZAIC/IAGOS partial column with the modelled ratio of the modelled (a priori) total column over the modelled (a priori) partial column. An evaluation of results from both methods yielded very similar total column estimates (de Laat et al., 2012), indicating that results are robust with regard to the choice of correcting for the "missing" part in the MOZAIC/IAGOS profiles.

\subsubsection{MOPITT collocations along MOZAIC/IAGOS profile path}

Because the MOZAIC/IAGOS profile measurements de facto are not true vertical profiles but rather follow a sort of a slant path through the atmosphere during ascent and descent of the aircraft - see later Sect. 5 and Fig. 5 - the horizontal distance covered by the MOZAIC/IAGOS profiles typically ranges from 200 to $400 \mathrm{~km}$, with minimum and maximum distances covered for the data used in this study varying between 71 and $444 \mathrm{~km}$ with a mean and median distances both just over $300 \mathrm{~km}$.

For the comparison with MOPITT NIR measurements, we define a collocation with MOZAIC/IAGOS as follows: measurement should be made during the same day (UTC time), and the MOPITT pixel center should be collocated within $25 \mathrm{~km}$ of the MOZAIC/IAGOS profile path. The number of MOPITT collocations per MOZAIC/IAGOS profile varies strongly as - apart from the MOPITT pixels size and orbit width - cloud cover and land-sea masks also play a role. For approximately $50 \%$ of the MOZAIC/IAGOS measurements, there are 10 or more MOPITT collocations. This percentage gradually decreases with increasing number of collocations: for $25 / 10 / 5 \%$ of the MOZAIC/IAGOS sub-columns, there are more than 19/27/32 MOPITT collocations, respectively (see Supplement Table S1). The maximum number of MOPITT collocations for a MOZAIC/IAGOS profile was 46. Hence, it is important to realize that each MOZAIC/IAGOS profile measurement typically is assigned to multiple MOPITT measurements.

\subsubsection{MOPITT averaging kernels and MOPITT a priori}

The MOPITT averaging kernels are applied to the logarithm of the MOZAIC/IAGOS mixing ratio profiles, following Rodgers et al. (2000):

comparison profile $=x_{\mathrm{a}}^{10 \log }+A_{\mathrm{MOP}}\left(x_{\mathrm{MI}}^{10 \log }-x_{\mathrm{a}}^{10 \log }\right)$,

in which $x_{\mathrm{MI}}$ is the MOZAIC/IAGOS $\mathrm{CO}$ profile, $x_{\mathrm{a}}$ is the MOPITT a priori CO profile, $10 \log$ indicates the logarithm of the $\mathrm{CO}$ mixing ratio profile and $A_{\mathrm{MOP}}$ is $\mathrm{MO}$ PITT the averaging kernel. After this convolution, the profile is converted back from $10 \mathrm{log}$ values to mixing ratios and vertically integrated to a total column. Subsequently, the higher vertical resolution MOZAIC/IAGOS CO profile is mapped (averaged) onto lower the MOPITT vertical resolution, whereby we ensure that the total column value of the averaged MOZAIC/IAGOS CO profiles is not altered.

Furthermore, since each MOPITT profile measurement comes with its own averaging kernel and a priori, the "comparison profile" as described above will be different for each MOPITT collocation, even though there is only one MOZAIC/IAGOS profile. The variation in the smoothed MOZAIC/IAGOS total columns due to the multiple MOPITT measurements collocated with MOZAIC/IAGOS is less than $2.5 / 3.5 / 6 \%$ for 90/95/99\% of the MOZAIC/IAGOS total column values, respectively. This is roughly equal to or less than the single MOZAIC/IAGOS measurement error. About half of this effect is related to spatial differences in the MOPITT a priori, the other half is related to differences in the MOPITT averaging kernel shape. Thus, variations in MOZAIC/IAGOS CO total columns due to different MOPITT averaging kernels are relatively small. This effect does not vary with changing number of MOPITT collocations, i.e. for either more or less collocations between MOZAIC/IAGOS and MOPITT these statistics remain similar. Although this is a small effect, it is not insignificant and should be kept in mind when interpreting the comparison.

\subsubsection{Synthesis}

In summary, the following steps are taken before MOZAIC/IAGOS and MOPITT measurements are compared and the comparisons are analysed:

- MOZAIC/IAGOS profile should reach at least $300 \mathrm{hPa}$;

- MOZAIC/IAGOS profile must have measurement in every $100 \mathrm{hPa}$ altitude bin;

- MOZAIC/IAGOS profile above maximum altitude is extended with the MOPITT a priori;

- MOPITT profiles must start below $800 \mathrm{hPa}$;

- MOPITT measurements are collocated with MOZAIC/IAGOS if the pixel centre lies within $25 \mathrm{~km}$ distance of the MOZAIC/IAGOS flight path; 
- Every single MOPITT measurement collocated with a MOZAIC/IAGOS flight path is considered a collocation with that MOZAIC/IAGOS measurement, resulting in multiple collocations with a single MOZAIC/IAGOS profile measurement;

- MOPITT averaging kernels and a priori profiles are applied to the vertically extended MOZAIC/IAGOS profiles for each single MOPITT collocation;

- After convolution with the MOPITT averaging kernels and a priori profiles, the MOZAIC/IAGOS profiles are vertically integrated to total columns for comparison with MOPITT total columns.

\subsubsection{MOCAGE}

To investigate the representation of a $\mathrm{CO}$ total column based on the MOZAIC/IAGOS profile measurements - which covers a horizontal distance - compared to true total CO columns as measured by MOPITT, results from a high-resolution $\left(0.2^{\circ} \times 0.2^{\circ}\right)$ simulation of the regional chemistry-transport model MOCAGE have also been analysed.

The MOCAGE model (MOdèle de Chimie Atmosphérique à Grande Echelle) (Peuch et al., 1999) is a 3-D CTM which covers the planetary boundary layer, the free troposphere and the stratosphere. It provides a number of optional configurations with varying domain geometries and resolutions, as well as chemical and physical parametrization packages. It has the flexibility to use several chemical schemes for stratospheric and tropospheric studies. For example, the MOCAGE main scheme is a detailed chemical scheme with 89 prognostic variables and 372 reactions.

MOCAGE is used for several applications: operational chemical weather forecasting in Météo-France (Dufour et al., 2004), tropospheric as well as stratospheric research studies (e.g. Josse et al., 2004; Michou et al., 2005; Ricaud et al., 2009a, b), and data assimilation research (e.g. Cathala et al., 2003; Pradier et al., 2006; Clark et al., 2007; Semane et al., 2007; El Amraoui et al., 2008a, b; Semane et al., 2009). MOCAGE can be forced dynamically by external wind and temperature fields from the Météo-France reanalysis ARPEGE (Action de Recherche Petite Echelle Grande Echelle).

The MOCAGE simulations used in this paper were performed within the ESA-ISOTROP project (see Acknowledgements). We only use the results of free runs from the ISOTROP ozone Nature runs over a European domain (see later Fig. 5) for two periods lasting three months (June 2003-August 2003 and November 2003-January 2004). For these simulations, anthropogenic emissions are based on the TNO-MACC emission inventory used for the LOTOS-EUROS model at $0.2^{\circ} \times 0.2^{\circ}$ resolution (Kuenen et al., 2011; Denier van der Gon et al., 2010), complemented by EMEP $0.5^{\circ} \times 0.5^{\circ}$ shipping emissions. No seasonal variability of these anthropogenic emissions is assumed. The biogenic emissions are available on the model resolution but fixed per month following Simpson et al. (2003). Biomass burning emissions are based on GFED V3 (daily on $1^{\circ} \times 1^{\circ}$ ).

\section{Validation statistics}

Figure 1a shows the $\mathrm{CO}$ total column comparison of all 8980 MOZAIC/IAGOS-MOPITT collocation pairs for the 2002-2010 period. The majority of MOZAIC/IAGOS columns fall within the MOPITT range of measurements along the profile path. Furthermore, the larger the number of MOPITT collocations for a given MOZAIC/IAGOS column, the more likely it becomes that the MOZAIC/IAGOS column falls within the MOPITT range of measurements along the profile path (see Supplement Table S1). Due to the large spatial extent of a single MOZAIC/IAGOS measurement, the number of collocations for a single MOZAIC/IAGOS profile measurement can be as large as 46 MOPITT measurements. The variability in MOPITT CO total columns along the MOZAIC/IAGOS flight path is represented by the vertical bars in Fig. 1a. The results indicate that MOPITT CO variability is very large along the MOZAIC/IAGOS profile path, and this range is larger than the one seen in the comparison with the NOAA aircraft data as presented in Deeter et al. (2013; their Fig. 4). Nevertheless, the correlation between MOPITT and MOZAIC/IAGOS CO total columns is still similar between both studies and the bias is slightly smaller (see Table 1).

Due to the large spread of MOPITT CO total columns along the MOZAIC/IAGOS profile path, we also recalculated the statistics using the following procedure (the so-called "range" data): if the MOZAIC/IAGOS column falls within the range of MOPITT columns along the MOZAIC/IAGOS profile path, we assume that there is no MOPITT bias (in practice one sets the average MOPITT column along the MOZAIC/IAGOS profile path equal to the MOZAIC/IAGOS column). Although by far not a perfect method to account for the CO total column variability along the MOZAIC/IAGOS profile path, this method provides a first-order estimate of how sub-MOZAIC/IAGOS profile path $\mathrm{CO}$ variability affects the validation. When taking this into account, the statistics of the comparison between MOPITT and MOZAIC/IAGOS become very similar to those from Deeter et al. (2013), showing that results are sensitive to the $\mathrm{CO}$ total column variability along the MOZAIC/IAGOS profile path.

The scatter distribution shown in Fig. $1 \mathrm{~b}$ and $\mathrm{c}$ provides a better view of the measurement density of Fig. 1a. Most of the MOPITT measurements are actually close to the MOZAIC/IAGOS measurements, and near the $1: 1$ line. Approximately $78 \%$ of the columns agree within $10 \%$ of each other and $95 \%$ of the columns agree within $20 \%$ of each other. 
Table 1. Statistics of MOPITT-MOZAIC/IAGOS CO total column comparison for the 2002-2010 period as well as similar validation results from Deeter et al. (2013). For the "mean" comparison, the average of all MOPITT measurements along the MOZAIC/IAGOS profile path is taken. For the "range" comparison, it is assumed that if the MOZAIC/IAGOS column falls within the range of MOPITT total column measurements along the MOZAIC/IAGOS flight path, the MOPITT column equals the MOZAIC/IAGOS column. The last two columns show results from the MOCAGE model simulation sampled for MOPITT/MOZAIC/IAGOS collocations as discussed in Sect. 5 and shown in Fig. 7 (MOCAGE), and the corresponding results for the comparison between MOPITT and MOZAIC/IAGOS (MMI) during the same period and for the same region. Note that the MOCAGE model simulation only covers two 3-month periods in 2003 and 2004 . Bias and root-mean-square values are in $10^{18}$ molecules $\mathrm{cm}^{-2}$.

\begin{tabular}{llllll}
\hline & Mean & "Range" & $\begin{array}{l}\text { Deeter et } \\
\text { al. }(2013)\end{array}$ & MOCAGE & MMI \\
\hline Bias $\left(\times 10^{18}\right)$ & 0.00 & 0.00 & 0.08 & 0.00 & 0.00 \\
Root-mean-square $\left(\times 10^{18}\right)$ & 0.23 & 0.18 & 0.17 & 0.18 & 0.18 \\
Correlation & 0.86 & 0.91 & 0.91 & 0.79 & 0.67 \\
\hline
\end{tabular}

Figure $2 \mathrm{a}$ shows the time series of all MOZAIC/IAGOS-MOPITT collocation differences. As already indicated in Fig. 1a, there is a considerable variability in differences for individual comparisons. Nevertheless, calculating the drift based on an ordinary linear regression indicates no statistically significant drift $(2 \sigma)$ in the differences over the period 2002-2010 which is consistent with results from Deeter et al. (2013; see Table 1). Figure 2b shows similar results as in Fig. 2 a but for monthly means. Indicated in Fig. $2 b$ is also the number of measurements that constitute the monthly mean. The use of monthly means reduces the variability to a large extent. The regression statistics still indicate no statistically significant drift in the differences, despite considerable month-to-month differences.

To further investigate the MOZAIC/IAGOS-MOPITT comparison, the same analysis was performed for four different areas: Europe (Fig. 2c, d), North America (Fig. 2e, f), Asia (Fig. 2g, h) and the rest of the world (Fig. 2i, j). The corresponding time series for a select number of representative airports can be found in Supplement Figs. S1 and S2. Table 2 summarizes the results of the regressions for these regions. For North America, no statistically significant drift in the differences is detected. For Europe we see a statistically significant but very small drift in the raw data but not in the monthly mean data. Note that the significance level of the regression is smaller for the raw data than for the monthly mean data, despite a much larger range in the raw data. This suggests that the use of a standard linear regression is not fully appropriate for the raw data.

For Asia, a statistically significant drift in the differences of $-0.04 \pm 0.0210^{18}$ molecules $\mathrm{cm}^{-2}$ is detected in both raw and monthly mean data. For the rest of the world, excluding Windhoek to avoid that Windhoek dominates the statistics as Windhoek by far provides the most measurement points and has a particularly strong seasonal cycle and thus large range of column values (see Supplement Table S2), there is no significant drift in both the raw data and the monthly mean data.
The data density for Asia is much smaller than for Europe or North America (see probability distributions in Fig. 2d and f). In particular, after 2006 only data from Hyderabad are available. Since Hyderabad shows a small negative bias (see Supplement Fig. S2-F), it is likely that the drift for Asia is artificial. To test this idea, the regression statistics were calculated after correcting the Hyderabad data for bias compared to MOZAIC/IAGOS and results are included in Table 2. Clearly, the drift becomes insignificant after correcting for the Hyderabad bias, confirming that care has to be taken with calculating drifts based on combined data.

\section{Individual station data}

Figure 3 shows an example of the comparison between MOPITT and MOZAIC/IAGOS based total column measurements for Windhoek, Namibia, which is a location with a particularly strong seasonal cycle due to strong biomass burning emissions in this region between August and November. MOPITT and MOZAIC/IAGOS compare very well with regard to the absolute column values and the seasonal cycle. However, the MOPITT data show a considerable spread among the MOPITT measurements collocated with the MOZAIC/IAGOS measurements. Nevertheless, compared to the MOPITT a priori statistics, the actual MOPITT measurements compare better for all statistical measures (MOPITT a priori statistics vs. measurements: slope increases from 0.70 to $0.95 ; R^{2}$ increases from 0.43 to 0.66 , RMS differences decrease from $0.2410^{18}$ to $0.1910^{18}$ molecules $\mathrm{cm}^{-2}$ ). In addition, the MOPITT measurements capture the high outliers during the biomass burning season (August-October) that are not present in the a priori data, thus proving that the MOPITT measurements do add value to the a priori MOPITT data. Furthermore, when considering the MOPITT variability along the MOZAIC/IAGOS profile path (the "range" data; see Sect. 3, Table 1) statistics improve even further for both the correlation and the root-mean-square differences. In addition, there is no significant drift in the differences during 

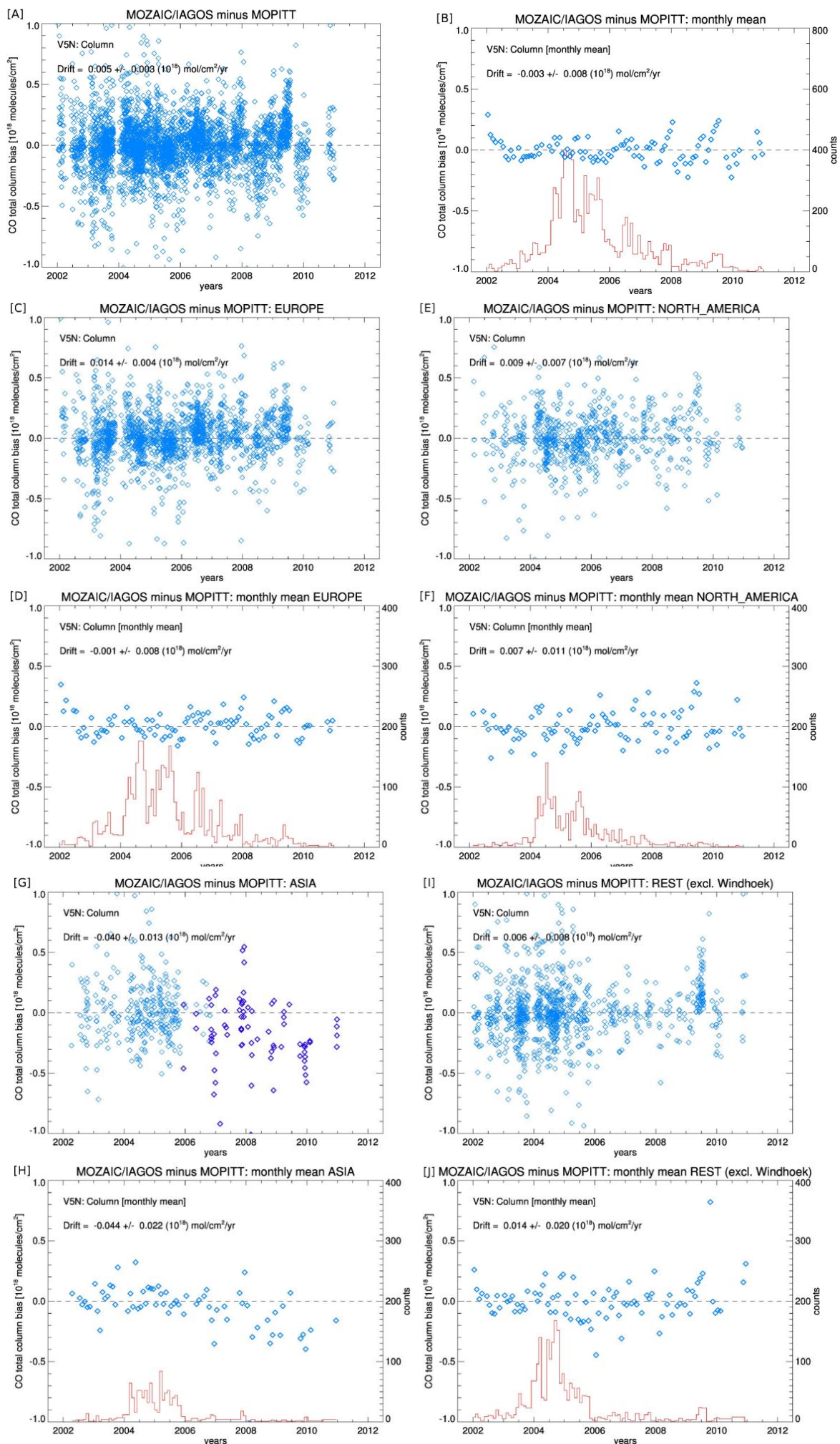

Figure 2. Time series plots showing the MOPITT bias trends based on the comparison with MOZAIC/IAGOS. (a) shows the comparison for all data, i.e. all MOPITT total columns collocated with MOZAIC/IAGOS measurements. The lower plot (b) shows the comparison based on monthly means and includes the number of measurements that comprise the monthly means (red line). (c, d) and (e, f) are similar to (a, b) but for Europe and North America only, respectively. $(\mathbf{g}, \mathbf{h})$ and $(\mathbf{i}, \mathbf{j})$ are similar to $(\mathbf{a}, \mathbf{b})$ but for Asia and the Rest of the World (excluding Windhoek, Namibia), respectively. The dark blue squares in the upper left plot show the Hyderabad measurements. 
Table 2. Regression statistics of MOZAIC/IAGOS-MOPITT differences for the period 2002-2010 for all data (Raw) as well as monthly means. For North America, data from the airports of Philadelphia, New York, Washington, Toronto, Montreal, Dallas, Atlanta, Vancouver, Portland and Los Angeles are used. For Europe, data from Frankfurt, Munich, Vienna and London are used. For Asia, data from Osaka, Tokyo, Beijing, Hyderabad and Teheran are used. Values are in molecules $\mathrm{cm}^{-2}$ year ${ }^{-1}$, uncertainties denote the $1 \sigma$ value. Figure $2 \mathrm{c}-\mathrm{j}$ show the figures corresponding to the North America, Europe, Asia and Rest-of-the-world data in a similar fashion as Fig. 2a and b. Rest-of-theworld data combine all locations not covered by the North America, Europe and Asia statistics and also exclude Windhoek, Namibia.

\begin{tabular}{lrrr}
\hline & Raw & Monthly & Deeter et al. (2013) \\
\hline Global & $0.005 \pm 0.003 \times 10^{18}$ & $0.003 \pm 0.008 \times 10^{18}$ & $-0.003 \pm 0.004 \times 10^{18}$ \\
North America & $0.009 \pm 0.007 \times 10^{18}$ & $0.007 \pm 0.011 \times 10^{18}$ & \\
Europe & $0.014 \pm 0.004 \times 10^{18}$ & $-0.001 \pm 0.008 \times 10^{18}$ & \\
Asia & $-0.040 \pm 0.013 \times 10^{18}$ & $-0.044 \pm 0.022 \times 10^{18}$ & \\
Asia & $-0.007 \pm 0.013 \times 10^{18}$ & $-0.013 \pm 0.036 \times 10^{18}$ & \\
Rest $^{2}$ & $0.006 \pm 0.008 \times 10^{18}$ & $0.014 \pm 0.020 \times 10^{18}$ & \\
\hline
\end{tabular}

${ }^{1}$ Drift statistics after correcting for the Hyderabad bias.

2 Drift statistics without Windhoek, Namibia

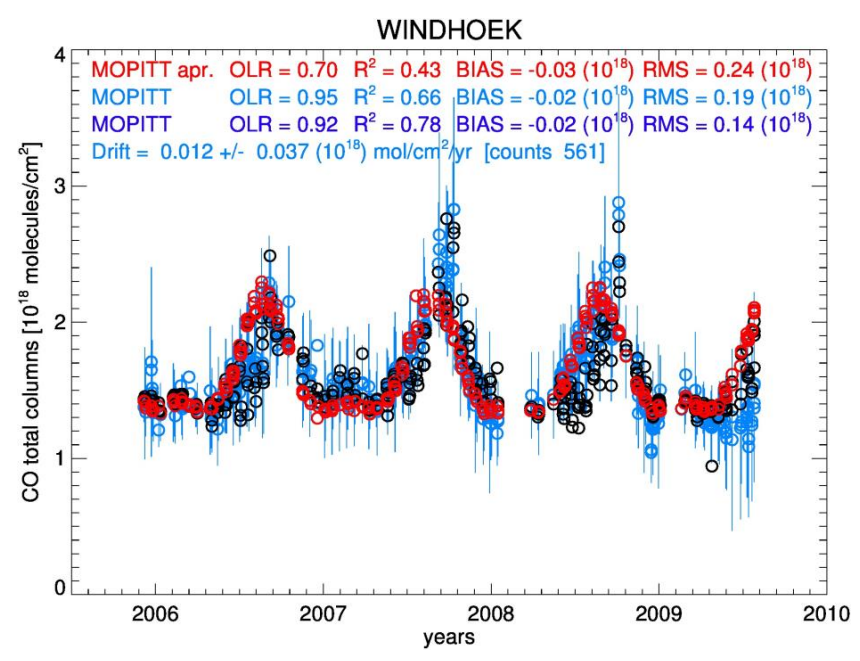

Figure 3. Time series of CO total columns at Windhoek, Namibia, for MOZAIC/IAGOS (black) as well as the MOPITT measurements (blue) and the MOPITT a priori (red). The MOPITT measurements show the mean (circle) and the range of MOPITT measurements (line) that coincide with a single MOZAIC/IAGOS measurement. The statistics represent the Ordinary Linear Regression (OLR) coefficient, the explained variance (square of correlation coefficient: $R^{2}$ ), the bias and the root-mean-square (RMS) differences. For the dark blue statistics (so-called "range"), we assume that if the MOZAIC/IAGOS column falls within the range of MOPITT total column measurements along the MOZAIC/IAGOS flight path, the MOPITT column equals the MOZAIC/IAGOS column. The drift statistics are calculated for the basic MOZAIC/IAGOS-MOPITT comparison without consideration of the MOPITT range along the MOZAIC/IAGOS flight path.

this period. Overall, the agreement between MOPITT and MOZAIC/IAGOS is very good for this particular location: the bias is insignificant, the root-mean-square difference is approximately $10 \%$ of the mean column and the correlation is $0.66\left(R^{2}\right)$, while the statistics improve when taking the MOPITT flight path variability into account $\left(R^{2}=0.78\right.$; smaller root-mean-square difference).

Figure $4 a-c$ show the statistics of the 35 airports with most collocations. Indicated are three parameters: correlation (a), bias (b) and root-mean-square differences (c). Each statistic is calculated for the average MOPITT column, the adjusted average MOPITT columns based on the observed MOPITT variability along the flight path ("range" data, see Sect. 3), and the MOPITT a priori.

In general, correlations are moderate to high, typically between 0.6 and 0.9 , and the statistics for the MOPITT "range" data are 0.05 to 0.1 points higher than for the average MOPITT data. However, correlations between MOZAIC/IAGOS and the MOPITT a priori are comparable to those between MOZAIC/AGOS and MOPITT measurements themselves, which is not surprising given that the MOPITT a priori is based on a 3-D climatology from a chemistry-transport model simulation and includes the seasonal cycle of $\mathrm{CO}$ which is the dominant mode of multi-year CO total column variability. Biases are generally smaller for the MOPITT data compared to the MOPITT a priori, and considerably smaller than the root-mean-square differences. Note that none of the drifts found for individual stations are statistically significant (see Supplement Figs. S1 and S2), confirming the results of the drifts calculated for the global and continental data shown in Fig. 2a-j.

Comparing the correlations and root-mean-square differences for the MOPITT a priori and the MOPITT "range" data shows that for about $60 \%$ of the cases the MOPITT "range" data statistics are better than the ones of the MOPITT a priori data (see also Supplement Table 2). Thus, for about $40 \%$ of the stations, even the MOPITT "range" data do not outperform the MOPITT a priori.

Clearly a somewhat mixed picture arises from the statistics of station-by-station comparison in Fig. 4. For a majority of stations, statistics of the comparison between MOPITT and MOZAIC/IAGOS improve relative to the comparison 

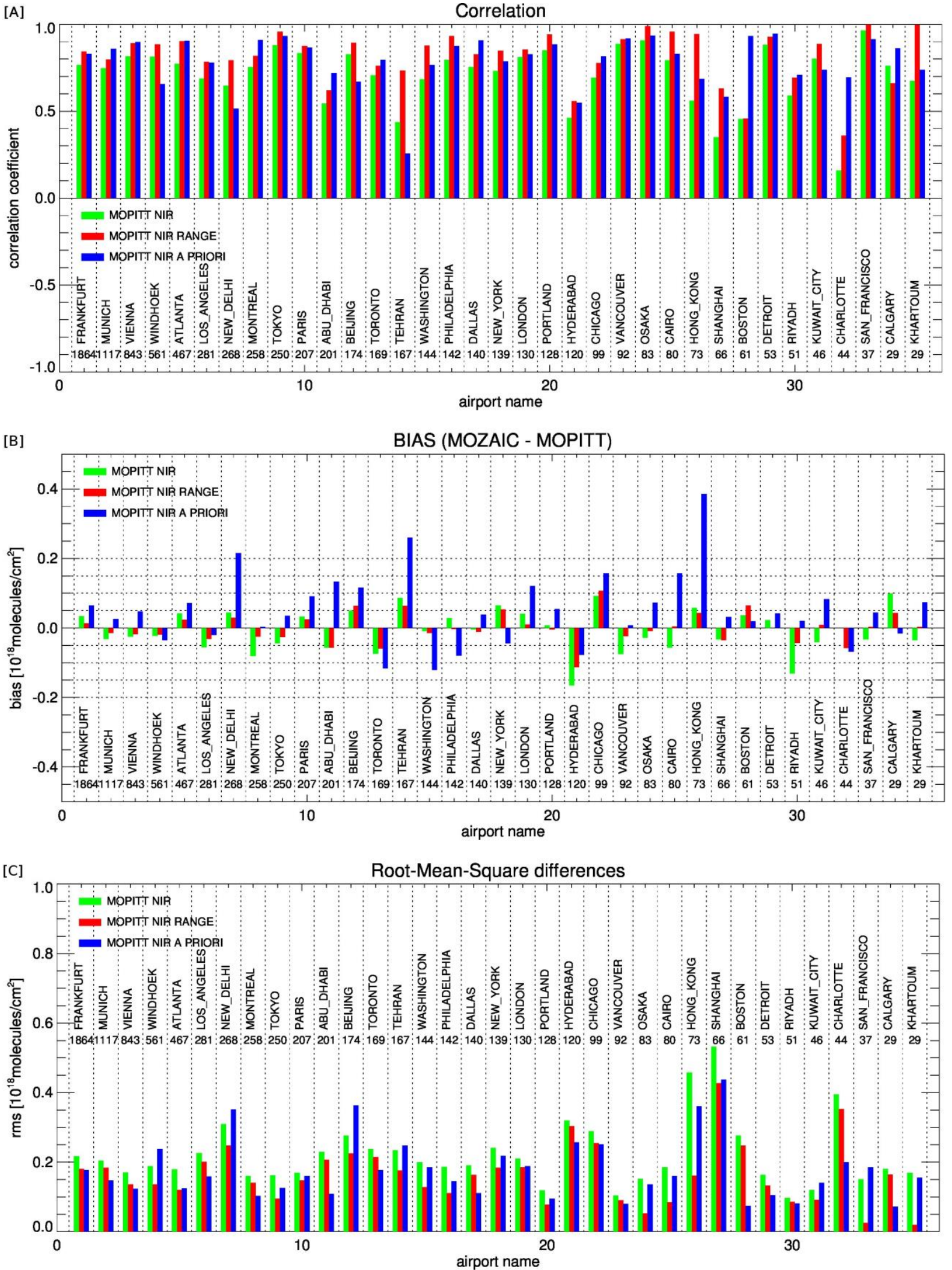

Figure 4. Statistics as shown in Fig. 3 for the 35 airport locations with the most MOPITT-MOZAIC/IAGOS collocations. The stations are ordered left to right according to decreasing number of collocations, indicated under the airport name. 
Table 3. Correlation statistics of the comparison between MOPITT and MOZAIC/IAGOS. The sigma value $\left(10^{18} \mathrm{molecules} \mathrm{cm}^{-2}\right)$ indicates the absolute threshold difference between MOZAIC/IAGOS and the MOPITT a priori for which the statistics are calculated. The "Threshold" row indicates whether the statistics are calculated based on the data selection for which the difference between MOZAIC/IAGOS and MOPITT a priori CO total columns is above or below the chosen threshold difference $(\Delta=0.3 / 0.4 / 0.5)$. The "Comparison" row indicates for which comparison the statistics are calculated (MOPITT a priori, "Apr", or MOZAIC/IAGOS, "MOZ"). Furthermore, a distinction is made between whether the mean MOPITT CO total column along the MOZAIC/IAGOS profile path is used (mean) or the MOPITT CO total columns after taking the MOPITT NIR column variability along the MOZAIC/IAGOS profile path into account (Range), as described in Sect. 3.

\begin{tabular}{|c|c|c|c|c|c|c|c|c|}
\hline \multirow[t]{2}{*}{$\begin{array}{l}\text { Column } \\
\text { Threshold }\end{array}$} & 1 & \multicolumn{3}{|c|}{$<\Delta$} & \multicolumn{4}{|c|}{$>\Delta$} \\
\hline & & \multicolumn{3}{|c|}{$R$} & & \multicolumn{3}{|c|}{$R$} \\
\hline Comparison & & Apr & MOZ mean & $\mathrm{MOZ}+\Delta$ & & Apr & MOZ mean & $\mathrm{MOZ}+\Delta$ \\
\hline$\Delta=0.3$ & $N=7965$ & 0.96 & 0.88 & 0.93 & $N=1015$ & 0.69 & 0.79 & 0.84 \\
\hline$\Delta=0.4$ & $N=8364$ & 0.95 & 0.88 & 0.93 & $N=616$ & 0.66 & 0.79 & 0.84 \\
\hline$\Delta=0.5$ & $N=8640$ & 0.93 & 0.88 & 0.92 & $N=340$ & 0.65 & 0.78 & 0.81 \\
\hline
\end{tabular}

between the MOPITT a priori and MOZAIC/IAGOS, something which is preferred, as otherwise the measurements would not add much to the a priori information.

However, a number of issues must be considered here. First of all, the MOPITT a priori is based on chemistrytransport model simulations of the MOZART model and includes seasonal variations, which is the most important variability in multi-year CO total column variations. Furthermore, MOPITT measurements themselves have errors which complicate matters. As a thought experiment, if the MOPITT a priori would perfectly match reality, the MOPITT retrieval would only worsen the measurement due to MOPITT errors from for example instrumental and calibration uncertainties, errors in retrieval parameters and imperfect retrieval methodologies.

To check whether MOPITT NIR measurements add value compared to the MOPITT a priori, one approach is to investigate the biases of the comparison between MOPITT and IAGOS/MOZAIC. Figure 4b shows that when comparing MOPITT with MOZAIC/IAGOS the majority of biases are - in the absolute sense - smaller for the MOPITT measurements comparison relative to the MOPITT a priori comparison by a factor of 2 or more (see also Table S2B).

A different approach for evaluating the added value of MOPITT NIR measurements is by assessing those situations where the MOZAIC/IAGOS measurements deviate significantly from the MOPITT a priori. It could be expected that particularly in those situations - the a priori deviates from reality - MOPITT adds information to the a priori. Based on an analysis similar to the one performed for Fig. 1 we checked the comparison of the MOPITT NIR and MOZAIC/IAGOS measurements for cases where the MOZAIC/IAGOS measurements deviated - in the absolute sense - more than $0.3 / 0.4 / 0.510^{18}$ molecules $\mathrm{cm}^{-2}$ from the MOPITT a priori (corresponding fractions of measurements qualifying for these filters are 11,7 and $4 \%$ of the to- tal number of MOZAIC/IAGOS measurements, respectively; see also Table 3). These are clearly the "outliers" for which one would expect MOPITT measurements to outperform the MOPITT a priori.

Table 3 shows the results of that comparison: for MOZAIC/IAGOS-MOPITT a priori differences within the threshold range $(<\Delta)$, the correlations between MOZAIC/IAGOS and the MOPITT a priori (0.93-0.96) are slightly better than the correlations between MOZAIC/IAGOS and the MOPITT NIR measurements (0.88-0.93; columns 3 and 4 in Table 3). However, correlations are very high and differences in the correlation coefficients are small $(0.01-0.08)$. On the other hand, for MOZAIC/IAGOS-MOPITT a priori differences outside the threshold $(>\Delta)$ range the MOPITT NIR measurements clearly outperform the MOPITT a priori: differences in correlation coefficients are 0.15-0.18 larger depending on the threshold value (columns $6 / 8$ in Table 3 ) for MOPITT NIR measurements compared to the MOPITT a priori. Even the MOPITT measurements that are not corrected for the MOZAIC/IAGOS flight path variability outperform the MOPITT a priori by $0.1-0.13$ according to their correlation (columns 6 and 7 in Table 3). This analysis shows that the MOPITT NIR measurements do "add value" to the MOPITT a priori for those conditions where one would expect this to occur.

\section{Model analysis: representation error}

The comparisons of total columns measurements based on MOZAIC/IAGOS profile data is hampered by the large horizontal distances covered by the MOZAIC/IAGOS aircraft during ascent and descent (see Figs. 1 and 2). Because MOZAIC/IAGOS operates on commercial airplanes, the traditional "spiraling" vertical profiling methodology 


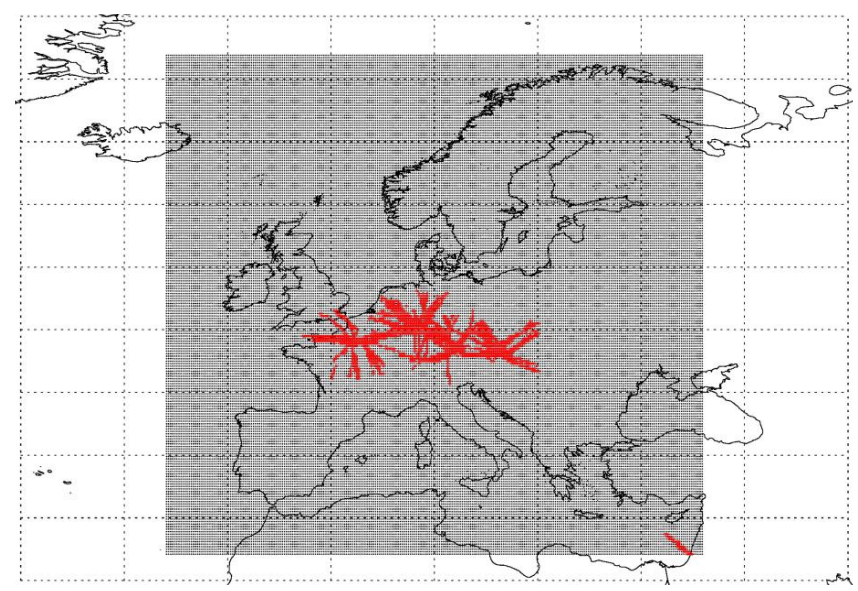

Figure 5. MOCAGE regional chemistry-transport model domain and corresponding MOZAIC/IAGOS profile measurements (flights paths; red) that were made during the two periods for which the MOCAGE simulations were available (June 2003-August 2003 and November 2003-January 2004).

commonly applied for validation of spaceborne vertical profiles during scientific field campaigns employing aircraft cannot be done. To get some indication of the effect the long horizontal distance covered by MOZAIC/IAGOS profiles has on comparisons with satellite $\mathrm{CO}$ total column measurements, we present results of a spatio-temporal high-resolution simulation by the MOCAGE model.

The simulations we analyse here were performed for the ISOTROP initiative. The simulation consists of two periods: June 2003-August 2003 and November 2003-January 2004 for a regional domain over Europe (Fig. $5 ; 16^{\circ} \mathrm{W}-36^{\circ} \mathrm{E}$, $32^{\circ} \mathrm{N}-72^{\circ} \mathrm{N}$ ). For the MOZAIC/IAGOS profile measurements made during this period and this region, the corresponding modelled $\mathrm{CO}$ concentrations collocated in space and time were determined, as well as the MOCAGE profiles collocated with the MOZAIC/IAGOS flight path. Figure 5 shows all MOZAIC/IAGOS flight paths at the model grid. Clearly the flight paths cover multiple model grids. The model results thus should provide a realistic estimate of the $\mathrm{CO}$ variability along MOZAIC/IAGOS flight paths.

Figure 6 shows an example of contrasting comparisons of MOZAIC/IAGOS and MOCAGE vertical profiles. Indicated in red are MOCAGE results for the true comparison with MOZAIC/IAGOS, and in grey the MOCAGE profiles collocated with the MOZAIC/IAGOS profile path. Note that overall, $\mathrm{CO}$ is underestimated in MOCAGE based on the comparison with MOZAIC/IAGOS, a common feature in chemistrytransport modelling (i.e. Shindell et al., 2006). The upper graphs (A, B) show two situations where there is relatively good agreement between MOCAGE and MOZAIC/IAGOS, the lower panels $(\mathrm{C}, \mathrm{D})$ show two situations where the agreement is much worse. The left plots $(\mathrm{A}, \mathrm{C})$ show situations where MOCAGE suggests small sub-MOZAIC/IAGOS pro- file path variability, and the right plots $(\mathrm{B}, \mathrm{D})$ show situations where MOCAGE suggests large sub-MOZAIC/IAGOS profile path variability. Clearly situations can differ very much from time to time and location to location. The difference between modelled and measured $\mathrm{CO}$ profile in plot $\mathrm{C}$ is likely related to Boreal forest fires. Summer 2003 was an active forest fire season in Siberia, in particular during May and June (Yurganov et al., 2005), and CO from these fires can quickly spread over the entire Northern Hemisphere (Damoah et al., 2004; Jaffe et al., 2004; Bertschi and Jaffe, 2005). However, the boundary conditions for the MOCAGE simulations are derived from a global simulation using monthly mean emissions, and cannot resolve plumes from single fires. Keep in mind that it is beyond the scope of this paper to analyse in detail the origin of differences between the MOCAGE simulation and MOZAIC/IAGOS (for example, Fig. 6c). We simply note here that, based on the comparison with MOZAIC/IAGOS, on average MOCAGE underestimates boundary layer CO by approximately $30 \%$ and free tropospheric $\mathrm{CO}$ up to $300 \mathrm{hPa}$ by approximately $15 \%$ (for the period investigated in the study).

Figure 7 shows the comparison between MOCAGE total columns based on the MOCAGE CO profiles along the MOZAIC/IAGOS flight path, and MOCAGE total columns based on MOCAGE CO profiles collocated with the MOZAIC/IAGOS flight path (similar to the comparison in Figs. 1 and 2). For convenience the corresponding MOZAIC/IAGOS CO total columns are also shown in red. The comparison shows that, similar to what was seen in the MOZAIC/IAGOS-MOPITT comparison in Figs. 1 and 2, there is a considerable spread among collocated MOCAGE total columns. The root-mean-square differences are similar to what was derived for the MOZAIC/IAGOS-MOPITT comparison. The correlation is somewhat smaller $(0.79$, compared to 0.91) due to the fact that the MOCAGE simulation does not cover a complete season and thus does not represent the full range of CO columns over the course of a season, as also indicated by the lower correlation for the comparison between MOPITT and MOZAIC/IAGOS for this region and during this period (see column MMI in Table 1). Nevertheless, the statistical similarity between the model results and the MOZAIC/IAGOS-MOPITT comparison indicates that the spread among MOZAIC/IAGOS collocated MOPITT NIR columns is indeed very likely related to CO variability.

\section{Summary, conclusions and discussion}

In this paper MOPITT V5 NIR CO total column measurements were validated against $\mathrm{CO}$ total columns based on MOZAIC/IAGOS profile measurements obtained for the period 2002-2010. Results from our comparison agree with those of Deeter et al. (2013) with NOAA aircraft data, a correlation of 0.86 , a root-mean-square difference 

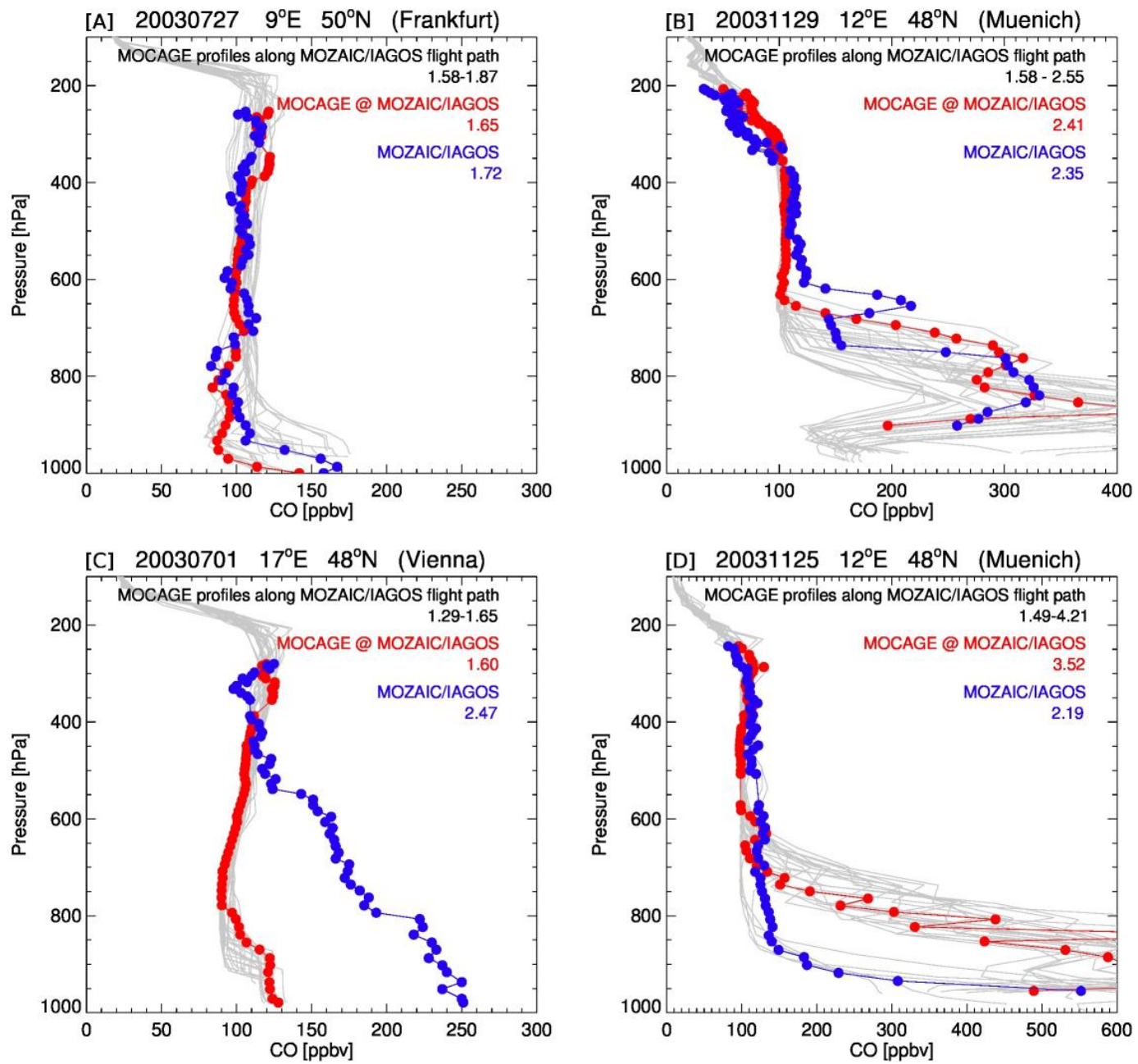

Figure 6. Comparisons between MOZAIC/IAGOS and MOCAGE CO profile measurements. The MOCAGE profiles collocated with the MOZAIC/IAGOS profile path are displayed in grey, the MOCAGE profile simulations exactly collocated with MOZAIC/IAGOS is in red. The corresponding MOZAIC/IAGOS profile is shown in blue. Indicated are also the date, the approximate geographical location of the MOZAIC/IAGOS profile measurement including departure or landing airport and the values of partial columns for the MOZAIC/IAGOS profile as well as the corresponding MOCAGE profile along the MOZAIC/IAGOS profile and the range of MOCAGE partial columns along the MOZAIC/IAGOS profile path (in $10^{18}$ molecules $\mathrm{cm}^{-2}$ ).

of $0.2310^{18}$ molecules $\mathrm{cm}^{-2}$ and no bias. When taking the MOPITT observed flight path $\mathrm{CO}$ column variability into account these numbers are 0.91 for the correlation, $0.1810^{18}$ molecules $\mathrm{cm}^{-2}$ for the root-mean-square differences and no bias. For Deeter et al. (2013) these numbers are a correlation of 0.91 and a root-mean-square difference of $0.1810^{18}$ molecules $\mathrm{cm}^{-2}$, and a bias of 0.08 $10^{18}$ molecules $\mathrm{cm}^{-2}$. No MOPITT V5 NIR bias was identified and no long-term drift - indicative for MOPITT calibration errors - was found, consistent with Deeter et al. (2013). In addition, correlations were similar, and also on regional scales no biases and drifts were found for the MOPITT-MOZAIC/IAGOS comparison.

Because MOPITT V5 NIR measurements are to some extent determined by the MOPITT a priori, it was also in- vestigated whether the validation results improve relative to the comparison between the MOPITT a priori and the MOZAIC/IAGOS measurements. It is by no means trivial that the validation results improve over the comparison with the MOPITT a priori: the MOPITT a priori is based on a global chemistry-transport model climatology that includes the seasonal cycle, geographical and vertical variations in $\mathrm{CO}$ that drive $\mathrm{CO}$ total column variability. To test whether there is added value in the MOPITT NIR CO measurements, MOZAIC/IAGOS measurements that deviated from the MOPITT a priori were used to validate the MOPITT NIR measurements. Results showed that the MOPITT NIR measurements outperformed the MOPITT a priori, showing that the MOPITT NIR measurements indeed "add value" to the MOPITT a priori. Additionally, biases between MOPITT and 


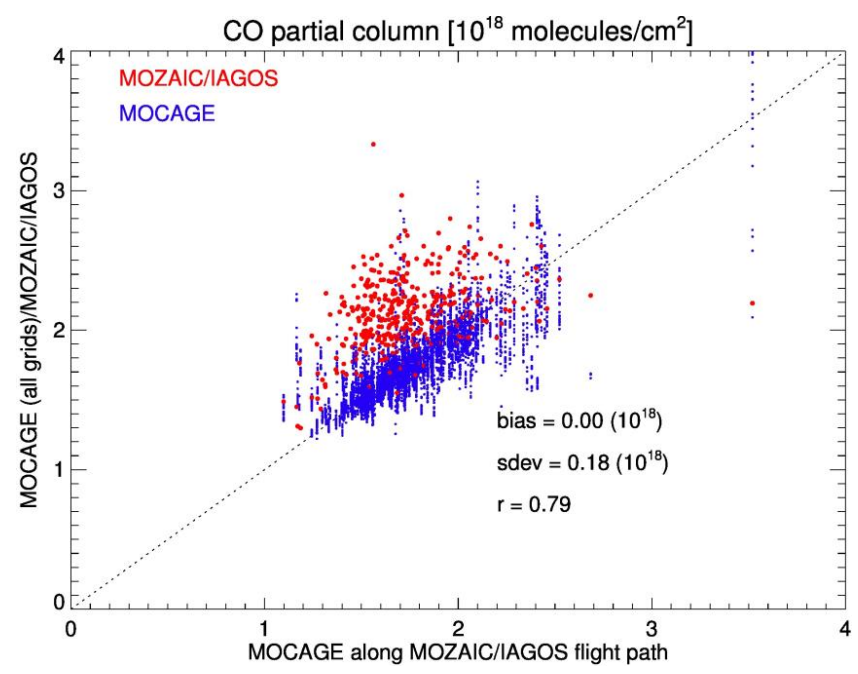

Figure 7. Comparison of all MOCAGE and MOZAIC/IAGOS partial CO column measurements made for the periods June 2003-August 2003 and November 2003-January 2004. No attempt was made to extend the profiles beyond the maximum measurement height; columns here thus represent partial columns. The horizontal axis shows the MOCAGE column based on the MOZAIC/IAGOS profile path collocations, the vertical axis shows the corresponding MOZAIC/IAGOS total column (red) and the MOCAGE CO columns collocated with the MOZAIC/IAGOS flight path profile (blue), the latter for which the statistics are also printed.

MOZAIC/IAGOS were - in absolute sense - smaller by a factor of 2 or more than biases between the MOPITT a priori and MOZAIC/IAGOS.

Validation of MOPITT measurements against MOZAIC/IAGOS measurements is hampered by the spatial footprint of MOZAIC/IAGOS measurements. The vertical profile of MOZAIC/IAGOS measurements obtained during take-off or landing of commercial aircraft typically covers between 200 and $400 \mathrm{~km}$. Results from high spatio-temporal simulations by the regional chemistrytransport model MOCAGE over Europe and collocated with MOZAIC/IAGOS measurements indicate that indeed there can be large variability in $\mathrm{CO}$ columns along the MOZAIC/IAGOS profile path. The CO column based on the MOZAIC/IAGOS profile measurements is thus not fully representative of the true vertical CO column, and this representation error has to be kept in mind. A comparison of MOPITT and MOZAIC/IAGOS using a simple methodology to assess this representation error indeed shows similar variability. However, there is no uniform general method to quantify the representation error. This error is location specific and depends on typical atmospheric transport patterns, and proximity of emission sources. It is therefore advised to carefully consider use of MOZAIC/IAGOS station by station.

The MOZAIC/IAGOS measurements nevertheless provide a highly valuable data set for validation of MOPITT
NIR CO total column measurements as they cover the entire MOPITT measurement period and provide information for locations not covered by the validation results presented in Deeter et al. (2013; only North America). Care has to be taken when comparing single MOZAIC/IAGOS measurements with MOPITT measurements due to the different air masses sampled. In addition, although the representation error of CO total column measurements based on MOZAIC/IAGOS data is not crucial for the comparison of $\mathrm{CO}$ total columns, use of MOZAIC/IAGOS measurements of for example ozone $\left(\mathrm{O}_{3}\right)$ or nitrogen dioxide $\left(\mathrm{NO}_{2}\right)$ to validate tropospheric ozone column measurements from satellites may be more sensitive to this representation error due to, for example, larger spatio-temporal variability.

Finally, it is worth mentioning that recent advances in assimilation of satellite measurements of $\mathrm{CO}$ can be useful for the validation of MOPITT CO. The assimilation results provide information that can be compared with both satellite as well as in situ measurements. Hence, they may bridge the "representation gap" between satellite and in situ measurements.

\section{The Supplement related to this article is available online at doi:10.5194/amt-7-3783-2014-supplement.}

Acknowledgements. The MOCAGE model simulation used in this study were performed within the ESA-ISOTROP project (European Space Agency - Impact of Spaceborne Observations on Tropospheric Composition Analysis and Forecast), ESA project 2012-2014, ESA Contract No: 4000105743.

Edited by: M. Portabella

\section{References}

Bertschi, I. T. and Jaffe, D. A.: Long-range transport of ozone, carbon monoxide, and aerosols to the NE Pacific troposphere during the summer of 2003: Observations of smoke plumes from Asian boreal fires, J. Geophys. Res., 110, D05303, doi:10.1029/2004JD005135, 2005.

Buchwitz, M., de Beek, R., Bramstedt, K., Noël, S., Bovensmann, H., and Burrows, J. P.: Global carbon monoxide as retrieved from SCIAMACHY by WFM-DOAS, Atmos. Chem. Phys., 4, 1945-1960, doi:10.5194/acp-4-1945-2004, 2004.

Buchwitz, M., de Beek, R., Noël, S., Burrows, J. P., Bovensmann, H., Schneising, O., Khlystova, I., Bruns, M., Bremer, H., Bergamaschi, P., Körner, S., and Heimann, M.: Atmospheric carbon gases retrieved from SCIAMACHY by WFM-DOAS: version $0.5 \mathrm{CO}$ and $\mathrm{CH}_{4}$ and impact of calibration improvements on $\mathrm{CO}_{2}$ retrieval, Atmos. Chem. Phys., 6, 2727-2751, doi:10.5194/acp6-2727-2006, 2006.

Buchwitz, M., Khlystova, I., Bovensmann, H., and Burrows, J. P.: Three years of global carbon monoxide from SCIAMACHY: 
comparison with MOPITT and first results related to the detection of enhanced CO over cities, Atmos. Chem. Phys., 7, 2399-2411, doi:10.5194/acp-7-2399-2007, 2007.

Cathala, M.-L., Pailleux, J., and Peuch, V.-H.: Improving chemical simulations of the upper troposphere - lower stratosphere with sequential assimilation of MOZAIC data, Tellus B, 55, 1-10, 2003.

Clark, H. L., Cathala, M.-L., Teyssèdre, H., Cammas, J.-P., and Peuch, V.-H.: Cross- tropopause fluxes of ozone using assimilation of MOZAIC observations in a global CTM, Tellus, B, 59, 39-49, 2007.

Crutzen, P. J. and Zimmermann, P. H.: The changing photochemistry of the troposphere, Tellus A/B, 43, 136-151, 1991.

Dalsøren, S. B. and Isaksen, I. S. A.: CTM study of changes in tropospheric hydroxyl distribution 1990-2001 and its impact on methane, Geophys. Res. Lett., 33, L23811, doi:10.1029/2006GL027295, 2006.

Damoah, R., Spichtinger, N., Forster, C., James, P., Mattis, I., Wandinger, U., Beirle, S., Wagner, T., and Stohl, A.: Around the world in 17 days - hemispheric-scale transport of forest fire smoke from Russia in May 2003, Atmos. Chem. Phys., 4, 1311-1321, doi:10.5194/acp-4-1311-2004, 2004.

Deeter, M. N., Edwards, D. P., Gille, J. C., and Drummond, J. R.: CO retrievals based on MOPITT near-infrared observations, J. Geophys. Res., 114, D04303, doi:10.1029/2008JD010872, 2009.

Deeter, M., Edwards, D. P., Gille, J. C., Emmons, L., Francis, G. L., Ho, S.-P., Mao, D. Y., Worden, H. M., Drummond, J. R., and Novelli, P. C.: The MOPITT version 4 CO product: Algorithm enhancements, validation, and long-term stability, J. Geophys. Res., 115, D07306, doi:10.1029/2009JD013005, 2010.

Deeter, M. N., Worden, H. M., Gille, J. C., Edwards, D. P., Mao, D., and Drummond, J. R.: MOPITT multispectral CO retrievals: Origins and effects of geophysical radiance errors, J. Geophys. Res., 116, D15303, doi:10.1029/2011JD015703, 2011.

Deeter, M. N., Martínez-Alonso, S., Edwards, D. P., Emmons, L. K., Gille, J. C., Worden, H. M., Pittman, J. V., Daube, B. C., and Wofsy, S. C.: Validation of MOPITT Version 5 thermalinfrared, near-infrared, and multispectral carbon monoxide profile retrievals for 2000-2011, J. Geophys. Res. Atmos., 118, 6710-6725, 2013.

de Laat, A. T. J., Dijkstra, R., Schrijver, H., Nédélec, P., and Aben, I.: Validation of six years of SCIAMACHY carbon monoxide observations using MOZAIC CO profile measurements, Atmos. Meas. Tech., 5, 2133-2142, doi:10.5194/amt-5-2133-2012, 2012.

Denier van der Gon, H. A. C., Visschedijk, A., van den Brugh, H., and Droge, R., and Vorhaben, F\&E: "Strategien zur Verminderung der Feinstaubbelastung" - PAREST: a high resolution European emission data base for the year 2005, TNO-Report, TNO-034-UT-2010-01895_RPT-ML, Utrecht, 2010.

Dils, B., De Mazière, M., Müller, J. F., Blumenstock, T., Buchwitz, M., de Beek, R., Demoulin, P., Duchatelet, P., Fast, H., Frankenberg, C., Gloudemans, A., Griffith, D., Jones, N., Kerzenmacher, T., Kramer, I., Mahieu, E., Mellqvist, J., Mittermeier, R. L., Notholt, J., Rinsland, C. P., Schrijver, H., Smale, D., Strandberg, A., Straume, A. G., Stremme, W., Strong, K., Sussmann, R., Taylor, J., van den Broek, M., Velazco, V., Wagner, T., Warneke, T., Wiacek, A., and Wood, S.: Comparisons between SCIAMACHY and ground-based FTIR data for total columns of $\mathrm{CO}, \mathrm{CH}_{4}, \mathrm{CO}_{2}$ and $\mathrm{N}_{2} \mathrm{O}$, Atmos. Chem. Phys., 6, 1953-1976, doi:10.5194/acp6-1953-2006, 2006.

Dufour, A., Amodei, M., Ancellet, G., and Peuch, V.-H.: Observed and modelled "chemical weather" during ESCOMPTE, Atmos. Res., 74, 161-189, 2004.

El Amraoui, L., Peuch, V.-H., Ricaud, P., Massart, S., Semane, N., Teyssèdre, H., Cariolle, D., and Karcher, F.: Ozone loss in the 2002/2003 Arctic vortex deduced from the Assimilation of Odin/SMR $\mathrm{O}_{3}$ and $\mathrm{N}_{2} \mathrm{O}$ measurements: $\mathrm{N}_{2} \mathrm{O}$ as a dynamical tracer, Q. J. Roy. Meteor. Soc., 134, 217-228, 2008 a.

El Amraoui, L., Semane, N., Peuch, V.-H., and Santee, M. L.: Investigation of dynamical processes in the polar stratospheric vortex during the unusually cold winter 2004/2005, Geophys. Res. Lett., 35, L03803, doi:10.1029/2007GL031251, 2008b.

El Amraoui, L., Attié, J.-L., Semane, N., Claeyman, M., Peuch, V.H., Warner, J., Ricaud, P., Cammas, J.-P., Piacentini, A., Josse, B., Cariolle, D., Massart, S., and Bencherif, H.: Midlatitude stratosphere - troposphere exchange as diagnosed by MLS $\mathrm{O}_{3}$ and MOPITT CO assimilated fields, Atmos. Chem. Phys., 10, 2175-2194, doi:10.5194/acp-10-2175-2010, 2010.

Elguindi, N., Clark, H., Ordóñez, C., Thouret, V., Flemming, J., Stein, O., Huijnen, V., Moinat, P., Inness, A., Peuch, V.-H., Stohl, A., Turquety, S., Athier, G., Cammas, J.-P., and Schultz, M.: Current status of the ability of the GEMS/MACC models to reproduce the tropospheric $\mathrm{CO}$ vertical distribution as measured by MOZAIC, Geosci. Model Dev., 3, 501-518, doi:10.5194/gmd-3501-2010, 2010.

Emmons, L. K., Walters, S., Hess, P. G., Lamarque, J.-F., Pfister, G. G., Fillmore, D., Granier, C., Guenther, A., Kinnison, D., Laepple, T., Orlando, J., Tie, X., Tyndall, G., Wiedinmyer, C., Baughcum, S. L., and Kloster, S., Description and evaluation of the Model for Ozone and Related chemical Tracers, version 4 (MOZART-4), Geosci. Model Dev., 3, 43-67, doi:10.5194/gmd3-43-2010, 2010.

Ghude, S. D., Beig, G., Kulkarni, P. S., Kanawade, V. P., Fadnavis, S., Remedios, J. J., and Kulkarni, S. H.: Regional CO pollution over the Indian-subcontinent and various transport pathways as observed by MOPITT, Int. J. Remote Sens., 32, 6133-6148, 2011.

Gloudemans, A. M. S., Krol, M. C., Meirink, J. F., de Laat, A. T. J., van der Werf, G. R., Schrijver, H., van den Broek, M. M. P., and Aben, I.: Evidence for long-range transport of carbon monoxide in the Southern Hemisphere from SCIAMACHY observations, Geophys. Res. Lett., 33, L16807, doi:10.1029/2006GL026804, 2006.

Gloudemans, A. M. S., Schrijver, H., Hasekamp, O. P., and Aben, I.: Error analysis for $\mathrm{CO}$ and $\mathrm{CH}_{4}$ total column retrievals from SCIAMACHY 2.3 ?m spectra, Atmos. Chem. Phys., 8, 3999-4017, doi:10.5194/acp-8-3999-2008, 2008.

Guerova, G., Bey, I., Attié, J.-L., Martin, R. V., Cui, J., and Sprenger, M.: Impact of transatlantic transport episodes on summertime ozone in Europe, Atmos. Chem. Phys., 6, 2057-2072, doi:10.5194/acp-6-2057-2006, 2006.

Huijnen, V., Flemming, J., Kaiser, J. W., Inness, A., Leitão, J., Heil, A., Eskes, H. J., Schultz, M. G., Benedetti, A., Hadji-Lazaro, J., Dufour, G., and Eremenko, M.: Hindcast experiments of tropospheric composition during the summer 2010 fires over western Russia, Atmos. Chem. Phys., 12, 4341-4364, doi:10.5194/acp12-4341-2012, 2014. 
Inness, A., Baier, F., Benedetti, A., Bouarar, I., Chabrillat, S., Clark, H., Clerbaux, C., Coheur, P., Engelen, R. J., Errera, Q., Flemming, J., George, M., Granier, C., Hadji-Lazaro, J., Huijnen, V., Hurtmans, D., Jones, L., Kaiser, J. W., Kapsomenakis, J., Lefever, K., Leitão, J., Razinger, M., Richter, A., Schultz, M. G., Simmons, A. J., Suttie, M., Stein, O., Thépaut, J.-N., Thouret, V., Vrekoussis, M., Zerefos, C., and the MACC team: The MACC reanalysis: an 8 yr data set of atmospheric composition, Atmos. Chem. Phys., 13, 4073-4109, doi:10.5194/acp-13-4073-2013, 2013.

Jaffe, D., Bertschi, I., Jaeglé, L., Novelli, P., Reid, J. S., Tanimoto, H., Vingarzan, R., and Westphal, D. L.: Long-range transport of Siberian biomass burning emissions and impact on surface ozone in western North America, Geophys. Res. Lett., 31, L16106, doi:10.1029/2004GL020093, 2004.

Josse, B., Simon, P., and Peuch, V.-H.: Radon global simulation with the multiscale chemistry transport model MOCAGE, Tellus, 56, 339-356, 2004.

Kuenen, J., Denier van der Gon, H., Visschedijk, A., van der Brugh, H., and van Gijlswijk, R.: MACC European emission inventory for the years 2003-2007, TNO report, TNO-060-UT-5, 201100588, Utrecht, 2011.

Konovalov, I. B., Beekmann, M., Kuznetsova, I. N., Yurova, A., and Zvyagintsev, A. M.: Atmospheric impacts of the 2010 Russian wildfires: integrating modelling and measurements of an extreme air pollution episode in the Moscow region, Atmos. Chem. Phys., 11, 10031-10056, doi:10.5194/acp-11-10031-2011, 2011.

Marenco, A., Thouret, V., Nédélec, P., Smit, H., Helten, M., Kley, D., Karcher, F., Simon, P., Law, K., Pyle, J., Poschmann, G., Wrede, R. V., Hume, C., and Cook, T.: Measurements of ozone and water vapour by Airbus in-service aircraft: The MOZAIC airborne program, An overview, J. Geophys. Res., 103, 25631-25642, 1998.

Michou M., Laville, P., Serça, D., Fotiadi, A., Bouchou, P., and Peuch, V.-H.: Measured and modeled dry deposition velocities over the ESCOMPTE area, Atmos. Res., 74 , 89-116, 2005.

Montzka, S. A., Krol, M., Dlugokencky, E., Hall, B., Jöckel, P., and Lelieveld, J.: Small Interannual Variability of Global Atmospheric Hydroxyl, Science, 331, 67-69, 2011.

Nam, J., Wang, Y., Luo, C., and Chu, D. A.: Trans-Pacific transport of Asian dust and CO: accumulation of biomass burning CO in the subtropics and dipole structure of transport, Atmos. Chem. Phys., 10, 3297-3308, doi:10.5194/acp-10-3297-2010, 2010.

Nédélec, P., Cammas, J.-P., Thouret, V., Athier, G., Cousin, J.-M., Legrand, C., Abonnel, C., Lecoeur, F., Cayez, G., and Marizy, C.: An improved infrared carbon monoxide analyser for routine measurements aboard commercial Airbus aircraft: technical validation and first scientific results of the MOZAIC III programme, Atmos. Chem. Phys., 3, 1551-1564, doi:10.5194/acp-3-15512003, 2003.

Peuch, V.-H., Amodei, M., Barthet, T., Cathala, M.-L., Josse, B., Michou, M., and Simon, P.: MOCAGE, MOdèle de Chimie Atmosphérique à Grande Echelle, Proceedings of Météo-France workshop on atmospheric modelling, 33-36, 1999.

Pradier, S., Attié, J.-L., Chong, M., Escobar, J., Peuch, V.-H., Lamarque, J.-F., Kattatov, B., and Edwards, D.: Evaluation of 2001 springtime CO transport over West Africa using MOPITT $\mathrm{CO}$ measurements assimilated in a global chemistry transport model, Tellus B, 58, 163-176, 2006.
Ricaud, P., Attié, J.-L., Teyssèdre, H., El Amraoui, L., Peuch, V.H., Matricardi, M., and Schluessel, P.: Equatorial total column of nitrous oxide as measured by IASI on MetOp-A: implications for transport processes, Atmos. Chem. Phys., 9, 3947-3956, doi:10.5194/acp-9-3947-2009, 2009a.

Ricaud, P., Pommereau, J.-P., Attié, J.-L., Le Flochmoen, E., El Amraoui, L., Teyssèdre, H., Peuch, V.-H., Feng, W., and Chipperfield, M. P.: Equatorial transport as diagnosed from nitrous oxide variability, Atmos. Chem. Phys., 9, 8173-8188, doi:10.5194/acp9-8173-2009, 2009b.

Rodgers, C. D. (Ed.): Inverse methods for atmospheric sounding: theory and practice, Series on Atmospheric Oceanic and Planetary Physics, World Scientific Publishing, Singapore, 2, 256 pp., ISBN: 9789812813718, 2000.

Semane, N., Peuch, V.-H., El Amraoui, L., Bencherif, H., Massart, S., Cariolle, D., Attié, J.-L., and Abida, R.: An observed and analysed stratospheric ozone intrusion over the high Canadian Arctic UTLS region during the summer of 2003, Q. J. Roy. Meteor. Soc., 133, 171-178, 2007.

Semane, N., Peuch, V.-H., Pradier, S., Desroziers, G., El Amraoui, L., Brousseau, P., Massart, S.,Chapnik, B., and Peuch, A.: On the extraction of wind information from the assimilation of ozone profiles in Météo-France 4-D-Var operational NWP suite, Atmos. Chem. Phys., 9, 4855-4867, doi:10.5194/acp-9-4855-2009, 2009.

Shindell, D. T., Faluvegi, G., Stevenson, D. S., Krol, M. C., Emmons, L. K., Lamarque, J.-F., Petron, G., Dentener, F. J., Ellingsen, K., Schultz, M. G., Wild, O., Amann, M., Atherton, C. S., Bergmann, D. J., Bey, I., Butler, T., Cofala, J., Collins, W. J., Derwent, R. G., Doherty, R. M., Drevet, J., Eskes, H. J., Fiore, A. M., Gauss, M., Hauglustaine, D. A., Horowitz, L. W., Isaksen, I. S. A., Lawrence, M. G., Montanaro, V., Muller, J.-F., Pitari, G., Prather, M. J., Pyle, J. A., Rast, S., Rodriguez, J. M., Sanderson, M. G., Savage, N. H., Strahan, S. E., Sudo, K., Szopa, S., Unger, N., van Noije, T. P. C., and Zeng, G.: Multimodel simulations of carbon monoxide: comparison with observations and projected near-future changes, J. Geophys. Res., 111, D19306, doi:10.1029/2006JD007100, 2006.

Simpson, D., Fagerli, H., Jonson, J. E., Tsyro, S., Wind, P., and Tuovinen, J. P.: Transboundary acidification, eutrophication and ground level ozone in Europe, part 1: unified EMEP model description, Technical report, EMEP Report 1/2003, Norwegian meteorological Insitute, 2003.

Stein, O., Schultz, M. G., Bouarar, I., Clark, H., Huijnen, V., Gaudel, A., George, M., and Clerbaux, C.: On the wintertime low bias of Northern Hemisphere carbon monoxide in global model studies, Atmos. Chem. Phys. Discuss., 14, 245-301, doi:10.5194/acpd-14-245-2014, 2014.

Sussmann, R. and Buchwitz, M.: Initial validation of ENVISAT/SCIAMACHY columnar CO by FTIR profile retrievals at the Ground-Truthing Station Zugspitze, Atmos. Chem. Phys., 5, 1497-1503, doi:10.5194/acp-5-1497-2005, 2005.

Warneke, T., de Beek, R., Buchwitz, M., Notholt, J., Schulz, A., Velazco, V., and Schrems, O.: Shipborne solar absorption measurements of $\mathrm{CO}_{2}, \mathrm{CH}_{4}, \mathrm{~N}_{2} \mathrm{O}$ and $\mathrm{CO}$ and comparison with SCIAMACHY WFM-DOAS retrievals, Atmos. Chem. Phys., 5, 2029-2034, doi:10.5194/acp-5-2029-2005, 2005.

Worden, H. M., Deeter, M. N., Edwards, D. P., Gille, J. C., Drummond, J. R., and Nédélec, P.: Observations of near-surface carbon 
monoxide from space using MOPITT multispectral retrievals, J. Geophys. Res., 115, D18314, doi:10.1029/2010JD014242, 2010.

Worden, H. M., Deeter, M. N., Frankenberg, C., George, M., Nichitiu, F., Worden, J., Aben, I., Bowman, K. W., Clerbaux, C., Coheur, P. F., de Laat, A. T. J., Detweiler, R., Drummond, J. R., Edwards, D. P., Gille, J. C., Hurtmans, D., Luo, M., MartínezAlonso, S., Massie, S., Pfister, G., and Warner, J. X.: Decadal record of satellite carbon monoxide observations, Atmos. Chem. Phys., 13, 837-850, doi:10.5194/acp-13-837-2013, 2013.
Yurganov, L. N., Duchatelet, P., Dzhola, A. V., Edwards, D. P., Hase, F., Kramer, I., Mahieu, E., Mellqvist, J., Notholt, J., Novelli, P. C., Rockmann, A., Scheel, H. E., Schneider, M., Schulz, A., Strandberg, A., Sussmann, R., Tanimoto, H., Velazco, V., Drummond, J. R., and Gille, J. C.: Increased Northern Hemispheric carbon monoxide burden in the troposphere in 2002 and 2003 detected from the ground and from space, Atmos. Chem. Phys., 5, 563-573, doi:10.5194/acp-5-563-2005, 2005.

Zbinden, R. M., Thouret, V., Ricaud, P., Carminati, F., Cammas, J.P., and Nédélec, P.: Climatology of pure tropospheric profiles and column contents of ozone and carbon monoxide using MOZAIC in the mid-northern latitudes $\left(24^{\circ} \mathrm{N}\right.$ to $\left.50^{\circ} \mathrm{N}\right)$ from 1994 to 2009, Atmos. Chem. Phys., 13, 12363-12388, doi:10.5194/acp13-12363-2013, 2013. 